\title{
Anti-fertility Effect of Various Plants at Dayak Tribe to Swiss Webster Mice
}

\author{
Agus Haryono*, Yohanes Edy Gunawan, Suatma, Surisman Sumitro, Mohammad Rahmadur
}

Biology Education Program Study, Palangkaraya University, Palangkaraya, Indonesia

\begin{abstract}
Blumea balsamifera, Croton tiglium, Metroxylon sagu, and Fagraea racemosa are used as traditional antifertility of Dayak people in Central Kalimantan. These study aims at finding out the potential plants as antifertility with the use on Swiss Webster (SW) mice. Extracts of B. balsamifera, C. tiglium, M. sagu, and F. racemosa were administered by gavage at the dose level of $0.26 \mathrm{mg} / \mathrm{kg}$ body weight (b.w) to female of $\mathrm{SW}$ mice for 8 days to examine their estrous cycle. To determine the anti-fertility, the procedure was to administer $0.26 \mathrm{mg} / \mathrm{kg}$ b.w of plant extract by gavageto female SW mice and mated it with normal male of SW mice. Estrous cycle were analyzed every day for 9 days and the reproduction display was examined 15 days after fertilization. The results show that there is an inhibitation in estrous cycle, particularly on estrus and metestrus phases for all of the traditional plant extracts. The reproduction dis play shows a decrease in the number of live fetuses, number of corpus luteum and body weight of the dam mice treated. The decrease in the corpus luteum further and fetuses attributes antifertilty effect of extract to inhibit foliculogenesis. Out of four extracts tested, the extract of B. balsamifera seems to be more potential for antifertility activities when compared with other traditional plant extracts.
\end{abstract}

Keywords: acitivities of antifertility, Blumea balsamifera, Croton tiglium, Fagraea racemosa., Metroxylon sagu, Mus musculus

\section{INTRODUCTION}

Various medicinal plant extracts have been tested for their antifertility activity both in male and female animal models. The total 50 species are listed in the present as medical plants [1]. The inventory of medicinal plants in Gunung Mas and Kahayan Hilir, Central Kalimantan, has found four plants (Blumea balsamifera, Croton tiglium, Metroxylon sago, and Fagraea racemosa) that used as antifertility. All the four plants are most widely used and believed by society to regulate reproduction or empirically as antifertility $[2,3$, 4]. The parts of the plants which are used asthe traditional contraception to inhibit pregnancy and birth regulation are leaves or roots. A preliminary study on the compounds contained in the extracts of antifertility plants shows that it contains flavonoids, terpenoids, alkaloids and steroids.

B. balsamifera has several active substances in the form of sineol, borneol, limonene, camphor,

\footnotetext{
${ }^{*}$ Corresponding address:

Agus Haryono

Biology Education Program Study, Palangkaraya University, Jalan Yos Sudarso C-11, Palangkaraya, Indonesia 73112

E-mail: agusharyono64@yahoo.com
}

tannins, saponins, flavonoids and alkaloids; these are found in the fresh or dried leaves and roots [5]. C. tiglium contains steroids and terpenoids which could be developed into medicine to help people achieve the goal of the national family planning program. The leaves of F. racemosa contain various compounds, such as alkaloids, flavonoids, saponins, tannins, sterolsn, and terpenoids [6]. The types of chemicals in $M$. sago are unknown; yet, the root of $M$. sago can be used for regulating reproduction [7]. Thus, plants that contain steroids, flavonoids and alkaloids have the antifertility effect, and this effect is suspected to contain in B. balsamifera, C. tiglium, M. sago, and $F$. racemosa. These plants cause dis-ruption in the process of ovulation and fertiliza-tion as the Dayak people in Central Kalimantan believe.

\section{MATERIALS AND METHODS}

\section{Materials}

The Swiss Webster (SW) mice used in the current study were those at the age of 10-12 weeks old and weighed 25-35 g. The plant parts used from the four plants were shoots, roots, stems, and leaves which were extracted in the Laboratory of Pharmacy, School of Pharmacy, 
Bandung Institute of Technology, using water as the solvent

\section{Dosage and treatment}

The dose was $2.6 \mathrm{mg} / \mathrm{kg}$ body weigh (b.w) for each plant following the conversion table by Laurence and Bacharac [8]. The dam mice were treated by gavage ata dose of $2.6 \mathrm{mg} / \mathrm{kg} \mathrm{b.w}$, whereas the control mice were sterilized by using steril aqua bidest.

\section{Detection of estrous cycle and determine of anti-fertility effect of traditional plants}

The process of making vaginal smear was carried outin 8 days. The preparation slide was stained with methyline blue dried for 3-5 minutes and observed by using light microscopy [9, 10]. After 9 days of treatment, the dam of SW mice mated female mice by pairing them with male mice in the afternoon and the next day the vaginal plug was defined as 0 days gestation [11]. Then the the dam of SW mice were killed at 15 days of gestation by cervical dislocation and dissected.

\section{Data analyses}

The body weight of the dam, the number of the corpus luteum, and the number of implantation were analyzed by using t-test, percentage of pre-implantation loss, percentage of mortality and percentage of life fetuses which were measured by Wilcoxon test [12]. Anti-implantation and antifertility acti-vities were analyzed by using the equation adopted from Tafesse [13].

\section{RESULTS AND DISCUSSION}

The results of vaginal smear for the detection of estrous cycle in the treated group with a dose of $2.6 \mathrm{mg} / \mathrm{kg} \mathrm{b.w} \mathrm{of} \mathrm{extracts} \mathrm{from} \mathrm{C.} \mathrm{tiglium.,} F$. racemosa, $B$. balsamifera, and $M$. sago were different from the control group. In the control group, the normal estrous cycle was found and all phases were detected, both in estrous cycle I and II. In experiment which involved the extracts of $C$. tiglium, it was at the estrus and proestrus phases on the first day prior to the treatment; however, in the first and second estrous cycle, the estrus phase was dominant and longer. In the treatment with extracts from $F$. racemosa, the estrus phase was found to be more dominant and detectable longer than the other phases. In the second estrous cycle, the phase was found to vary more, and the longer phase of estrus only occurred in one dam mice. In the treated group with extracts from B. balsamifera, the early observation detected estrus and proestrus phases, and these were detected much longer than the other phases in both the first and second estrous cycle.The treatment with extracts of the roots of $M$. sago was initially dominated by estrus and proestrus phases. Later, the first estrous cycle turned into the estrus phase, and the second estrous cycle shows that the phase changes over a longer time ina more dominant metestrus phase.

Table 1. The results of the vaginal smear of the dam of Swiss Webster mice control group

\begin{tabular}{cccccccccc}
\hline \multirow{2}{*}{$\begin{array}{c}\text { No. of the } \\
\text { dam }\end{array}$} & \multicolumn{10}{c}{ Estrous cycle } \\
\cline { 2 - 9 } & 0 & 1 & 2 & 3 & 4 & 5 & 6 & 7 & 8 \\
1 & $\mathrm{E}$ & $\mathrm{D}$ & $\mathrm{D}$ & $\mathrm{P}$ & $\mathrm{M}$ & $\mathrm{E}$ & $\mathrm{D}$ & $\mathrm{D}$ & $\mathrm{P}$ \\
2 & $\mathrm{D}$ & $\mathrm{P}$ & $\mathrm{E}$ & $\mathrm{D}$ & $\mathrm{D}$ & $\mathrm{P}$ & $\mathrm{E}$ & $\mathrm{D}$ & $\mathrm{D}$ \\
3 & $\mathrm{P}$ & $\mathrm{E}$ & $\mathrm{E}$ & $\mathrm{D}$ & $\mathrm{D}$ & $\mathrm{P}$ & $\mathrm{M}$ & $\mathrm{D}$ & $\mathrm{D}$ \\
4 & $\mathrm{P}$ & $\mathrm{E}$ & $\mathrm{E}$ & $\mathrm{D}$ & $\mathrm{D}$ & $\mathrm{P}$ & $\mathrm{E}$ & $\mathrm{D}$ & $\mathrm{D}$ \\
5 & $\mathrm{E}$ & $\mathrm{E}$ & $\mathrm{D}$ & $\mathrm{D}$ & $\mathrm{P}$ & $\mathrm{M}$ & $\mathrm{D}$ & $\mathrm{D}$ & $\mathrm{P}$ \\
6 & $\mathrm{E}$ & $\mathrm{D}$ & $\mathrm{D}$ & $\mathrm{P}$ & $\mathrm{E}$ & $\mathrm{E}$ & $\mathrm{M}$ & $\mathrm{D}$ & $\mathrm{D}$ \\
\hline
\end{tabular}

Table 2. Vaginal smears of treated group with extract of B. balsamifera dose of $2.6 \mathrm{mg} / \mathrm{kg}$ bw administered by gavave to Swiss Webster mice

\begin{tabular}{|c|c|c|c|c|c|c|c|c|c|}
\hline \multirow{3}{*}{$\begin{array}{l}\text { No of } \\
\text { the dam }\end{array}$} & \multicolumn{9}{|c|}{ Estrous cycle } \\
\hline & \multicolumn{5}{|c|}{ I (Day...) } & \multicolumn{4}{|c|}{ I (Day...) } \\
\hline & 0 & 1 & 2 & 3 & 4 & 5 & 6 & 7 & 8 \\
\hline 1 & $\mathrm{P}$ & $\mathrm{E}$ & M & $\mathrm{P}$ & M & $\mathrm{E}$ & M & M & M \\
\hline 2 & $\mathrm{P}$ & $\mathrm{E}$ & $\mathrm{E}$ & $\mathrm{E}$ & $\mathrm{E}$ & $\mathrm{E}$ & $\mathrm{E}$ & $\mathrm{E}$ & $\mathrm{P}$ \\
\hline 3 & $\mathrm{E}$ & $\mathrm{P}$ & $\mathrm{P}$ & $\mathrm{P}$ & $\mathrm{P}$ & M & $\mathrm{P}$ & $\mathrm{E}$ & M \\
\hline 4 & E & D & $\mathrm{E}$ & M & $\mathrm{E}$ & $\mathrm{E}$ & $\mathrm{E}$ & M & $\mathrm{P}$ \\
\hline 5 & $\mathrm{P}$ & $\mathrm{E}$ & $\mathrm{P}$ & $\mathrm{E}$ & $\mathrm{E}$ & $\mathrm{E}$ & M & $\mathrm{E}$ & $\mathrm{P}$ \\
\hline 6 & $\mathrm{E}$ & $\mathrm{E}$ & $\mathrm{E}$ & $\mathrm{E}$ & $\mathrm{E}$ & M & $\mathrm{P}$ & E & M \\
\hline
\end{tabular}

Note: E : Estrus phase ; D: Diestrus phase ; M : Metestrus phase ; P : Proestrus phase 
The observation on the reproductive display of the dam group and the treated group with a dose of $2.6 \mathrm{mg} / \mathrm{kg}$ b.w extracts from the potential plants was listed in Table 3. The control group showed all the parameters, like the body weight of the dam $(29.61 \pm 1.28 \mathrm{~g})$, the number of corpus luteum (10.67 \pm 1.03$)$, and the empty data of dead fetuses.In the treatment with extracts from C. tiglium, the average body weight of the dam $(26.73 \pm 2.29 \mathrm{~g})$ was significantly lower when compared with those in the control group. Similarly, the number of corpus luteum $(6.83 \pm 4.12)$ is significantly less than the control group. The treatment with extracts from $F$. racemosa, the stem weight $(24.05 \pm 3.69 \mathrm{~g})$ was markedly lower than the control. Similarly, the average number of corpus luteum in the treatment group $(5.16 \pm$ 4.22) was markedly lower than the control, and half a number of dead fetuses was detected. The treatment with extracts from $B$. balsamifera, the average body weighs of mice dam $(22.46 \pm 2.11)$ was lower compared with control group. The number of the corpus luteum in the treatment group (1.5 \pm 1.76$)$ was markedly less than that in the control group. This is consistent with the discovery of the embryo as a result of fertilization; thus, the anti-fertility activity reached 100 $\%$. The treatment with extracts from the roots of $M$. sago also reduced the body weight of mice dam (27.44 \pm 1.38$)$ and the number of corpus luteum as compared to the controls, so the num- ber of fetuses in a very real life less than controls.

Among the four plants, the only plant that can be said as "potential" as the antifertility is $B$. balsamifera $(100 \%)$, while the other plants are not. It is shown by the corpus luteum and life fetuses which are formed as a result of good fertilization after the treatment with extract plants of C. tiglium, M. sago, and F. racemosa (Table 4).

\section{Discussion}

Changes in each phase of the estrous cycle of the control group in the first cycle are different from the normal conditions at the phase of estrus. However, in the second of estrous cycle, the condition is back to normal. The reason for this could be the fact that the disorder in the first cycle is caused by a lot of handling which leads to the abnormal pattern. After adaptation in a week apparently the estrous cycle changes back to normal.

Based on the results, the present study reveals that extracts from B. balsamifera, C tiglium, M. sago, and $F$. racemosa contain steroid and terpenoid; these are compounds that are proven to disrupt the estrous cycle and true resistance of diestrus phase, thus extending the estrus phase. It is also evident that the numbersof the corpus luteum in the treated group is less than that in the control group.

The formation of the ovum, in addition to morphological changes, also changes in hormone

Table 3. The effect of extract antifertiliy plants adminitered by gavage at doses $2,6 \mathrm{mg} / \mathrm{kg}$ bw to reproduction display of SW mice

\begin{tabular}{|c|c|c|c|c|c|c|}
\hline $\begin{array}{l}\text { Test material } \\
\text { (extract) }\end{array}$ & $\begin{array}{l}\text { Number of } \\
\text { dam }\end{array}$ & $\begin{array}{l}\text { Body weight } \\
\mathrm{X} \pm \mathrm{SD} \\
\text { a }\end{array}$ & $\begin{array}{l}\text { Total number of } \\
\text { the corpus } \\
\text { luteum } \\
\mathrm{X} \pm \mathrm{SD} \\
\text { a }\end{array}$ & $\begin{array}{l}\text { Abortus } \\
(\%) \\
\omega\end{array}$ & $\begin{array}{l}\text { Number of } \\
\text { Fetus life } \\
(\%) \\
\omega\end{array}$ & $\begin{array}{l}\text { The number } \\
\text { of dead } \\
\text { fetuses } \\
(\%) \\
\omega\end{array}$ \\
\hline Aquadest steril & 6 & $29,61 \pm 1,28$ & $\begin{array}{l}64 \\
10,67 \pm 1,03\end{array}$ & $\begin{array}{l}0 \\
(0)\end{array}$ & $\begin{array}{l}64 \\
(100)\end{array}$ & $\begin{array}{l}0 \\
(0)\end{array}$ \\
\hline C. tiglium & 6 & $26,72 \pm 2,29 *$ & $\begin{array}{l}41 \\
6,83 \pm 4,12^{* *}\end{array}$ & $\begin{array}{l}12^{* *} \\
(33,33)\end{array}$ & $\begin{array}{l}29 * * \\
(50)\end{array}$ & $\begin{array}{l}0 \\
(0)\end{array}$ \\
\hline F. racemosa & 6 & $24,05 \pm 3,6^{*}$ & $\begin{array}{l}31 \\
5,16 \pm 4,22 * *\end{array}$ & $\begin{array}{l}6^{* *} \\
(16,67)\end{array}$ & $\begin{array}{l}25^{* *} \\
(50)^{* *}\end{array}$ & $\begin{array}{l}0 \\
(0)\end{array}$ \\
\hline B. balsamifera & 6 & $22,46 \pm 2,11 * *$ & $\begin{array}{l}9 \\
1,5 \pm 1,7)^{* *}\end{array}$ & $\begin{array}{l}0 \\
(0)\end{array}$ & $\begin{array}{l}0^{* *} \\
(0)\end{array}$ & $\begin{array}{l}0 \\
(0)\end{array}$ \\
\hline M. sagu & 6 & $27,44 \pm 1,6^{*}$ & $\begin{array}{l}27 \\
4,5 \pm 5,3)^{* *}\end{array}$ & $\begin{array}{l}0 \\
(00\end{array}$ & $\begin{array}{l}27 * * \\
(50)\end{array}$ & $\begin{array}{l}0 \\
(0)\end{array}$ \\
\hline
\end{tabular}

Note: @: Student's t-test against the control

$\omega:$ Wilcoxon's test to control

SD: Standard Deviation

$*: \quad \mathrm{P}<0,05$

** $: \mathrm{P}<0,01$ 
Table.4 Analysis of antifertility and anti-implantation activity of traditional plant to SW mice

\begin{tabular}{|c|c|c|c|c|c|c|}
\hline \multirow{2}{*}{$\begin{array}{c}\text { Test material } \\
\text { (Extract of Plants) }\end{array}$} & \multirow{2}{*}{$\begin{array}{c}\text { Number of } \\
\text { dam }\end{array}$} & \multirow{2}{*}{$\begin{array}{c}\text { Animals } \\
\text { with } \\
\text { implantation }\end{array}$} & \multirow{2}{*}{$\begin{array}{c}\text { Animals } \\
\text { without } \\
\text { implantation }\end{array}$} & \multirow{2}{*}{$\begin{array}{c}\text { Total } \\
\text { implantation }\end{array}$} & \multicolumn{2}{|c|}{ Activity (\%) } \\
\hline & & & & & $\begin{array}{c}\text { Anti- } \\
\text { implantation }\end{array}$ & $\begin{array}{c}\text { Anti } \\
\text { Fertility }\end{array}$ \\
\hline Aquadest steril & 6 & 6 & 0 & 64 & 0 & 0 \\
\hline C. tiglium & 6 & 3 & 3 & 41 & 35 & 50 \\
\hline F. racemosa & 6 & 3 & 3 & 31 & 51 & 50 \\
\hline B. balsamifera & 6 & 0 & 6 & 0 & 0 & 100 \\
\hline Metroxylonsagu Rottb & 6 & 3 & 3 & 27 & 57 & 50 \\
\hline
\end{tabular}

pattern and content. The growth of egg follicle is affected by the concentration of FSH, while the ovulation usually occurs when the concen-tration of LH reaches optimum [14]. The ex-tracts of Azadiracta indica and Melia azedarach have been known to inhibit folliculogenesis to disrupt the formation of the body's hormonal [15]. The extracts of papaya seeds are suspected to be toxic, although it may work is selective [16]. In this study, the extracts of $B$. balsamifera, C. tiglium, $M$. sago, and $F$. racemosa in the estrous cycle I and II can inhibit the formation of egg follicles and direct entry into the estrous phase of the estrous cycle. It could be caused by steroid compounds and terpenoids which present in the extracts of B. balsamifera, C. tiglium, $M$. sago, and F. racemosa. Those substances can increase the production of $17 \beta$-estradiol, thereby increasing the concentration of $\mathrm{LH}$ and decreasing the FSH, leading to the egg follicles being induced to enter into the phase of estrus.

Antifertility activity of all four potential plants, that $B$. balsamifera more potetial than the other plants, the dam was given extract $B$. balsamifera by gavave cause no fetuses observed in the uterus at 15 days gestation. This is supported by the average number of corpus lutueum were also found very little, so the suspected the folliculogenesis not occured, although ovulation occurs, the ovum cell quality is not perfect. It was thought to be caused by the active compounds in the extract of $B$. balsamifera, which interfere the growth of egg follicles. Based on the results of the vaginal smear, estrus phase recovered from treated mice with $B$. balsamifera, the time required for a longer. This indicates that the eggs folicle do not develop and induced go into estrus phase, so although it is still in an immature primary follicles are stimulated to ovulation. $B$. balsamifera compounds with activity similar to $\mathrm{LH}$, or indirectly realase activate gonadotrophin hormone $(\mathrm{GnRH})$ to stimulate the formation of LH. B. balsamifera can increase production of 17 $\beta$-estradiol, thereby increasing the concentration of LH and FSH decreased and egg follicles be induced to enter into the phase of estrus.

\section{CONCLUSION}

The four plants used as antifertility by the Dayak tribesare empirically able to disrupt the estrous cycle by extending the phase of estrus and metestrus. However, B. balsamifera appears as the most potential plant as an antifertility by inhibiting fertilization.

\section{ACKNOWLEDGEMENTS}

The author would like to thank the Director of Higher Education for the financial support through fundamental research grant through the University Research Universitas Palangkaraya Number: 0720/023-04.2.01/17/2011, December 9, 2011 Budget 2012 in accordance with the letter of Fundamental Grant Implementation Agreement No. 802 / UN / 24/PL/2012 / dated March 22, 2012.

\section{REFERENCES}

1. Priya G, Saravanan K, Renuka CG (2012) Medicinal plants with potential antifertility activity - A review of sixteen years of herbal medicine research. J. Int. J. Pharm. Tech. Res. 4 (1): 481-494.

2. Reantina (1999) Inventarisasi tumbuhan obat tradisional yang dimanfaatkan untuk mengatur jarak kelahiran dalam empat desa di kecamatan Kahayan Hilir. Skripsi. Program Studi Pendidikan Biologi. Universitas Palangkaraya.

3. Elisabeth (2005) inventarisasi tumbuhan yang dimanfaatkan untuk kontrasepsi tradisional di Kecamatan Tewah Kabupaten Gunung Mas. Palangka Raya. Thesis. Universitas Palangka Raya.

4. Najamuddin, Akhmadi, Haryono A (2009). Study etnobotany tumbuhan obat di masyakarat suku Dayak Ngaju di Kapuas Hulu Kalimantan Tengah. Anterior Jurnal. 9 (1) ; 106-114. 
5. Arifin H, Widianingsih I, Marusin N (2007) Pengaruh pemberian akut ekstrak etanol daun Capo (Blumea basamifera D.C.) terhadap gambaran morfolofis dan histologi hati mencit putih jantan. Jurnal Sains dan Teknologi Farmasi 12 (2): 82-88.

6. Rachmi, E.\& Zubaidah, M. (2003). Fagraea racemosa Jack tanaman obat multiguna. http://bioscientiae.tripod.com. Accessed date: July, 2011.

7. Burton JL, Wells M (2006) The effect of phytoestrogens on the female genital Tract. J. Clin. Pathol. 55: 401-407.

8. Laurence J, Bacharach M (1964) Analytical Toxicology. CRC Press. Philadelphia.

9. Tryanti L (2001) Pengaruh $\alpha$-klorohidrin terhadap kemampuan reproduksi tikus sawah jantan. Tesis. Magister Program Pasca Sarjana Bandung, Institut Teknologi Bandung.

10. Goldman JM, Murr AS, Cooper RL (2007) The rodent estrous cycle: characterisation of vaginal cytology and its utility in toxicological studies. Birth Defects Research (Part B) 80: 84-97.
11. Taylor P (1986) Practical Teratology. Academis Press ING. Orlando, Florida.

12. Stell RG, Torrie JH (1989) Prinsip dan prosedur statistik. Penterjemah: Sumantri B. Gramedia. Jakarta.

13. Tafesse G, Yalemtsehay M, Eyasu M (2005) In vivo and in vitro anti-fertility and antiimplantation properties of leonotis ocymifolia in rats. Afr. J. Trad. CAM. 2 (2): 103 - 112.

14. Carlson MB (1988) Paten's foundations of embriology. Departement of Anatomy and Biologycal Sciences University of Michigan. New York.

15. Roop JK, Dhaliwal PK, Guraya SS (2005) Extracts of Azadirachta indica and Melia azedarach seeds inhibit folliculogenesis in albino rats. Brazilian J. Med. and Biol. Res. 38: 943-947.

16. Lohiya NK, Manivanman B, Mishra PK, Pathak N, Sriram S, Bhande SS, Pannerdoss S (2002) Cloroform extract of Carica papaya seeds induces long-term reversible azoosermia in langur monkey. Asian J Andro. 4 (1): 17-26. 